\title{
Talent Training in Commodities on the basis of "Six-dimensional Synergy" School-enterprise Cooperation
}

\author{
Yue $\mathrm{Hu}^{1, \mathrm{a}}$, Jun $\mathrm{Ma}^{2, \mathrm{~b}}$ \\ 1,2No.899 XueYue Road,YinZhou,Ningbo,Zhejiang,China \\ a396372439@qq.com, b1144896644@qq.com
}

\begin{abstract}
Key words: school-enterprise cooperation; commodities; applied; Talents
Abstract: School-enterprise cooperation is the key of training in applicable talents for colleges. In this paper, we take commodity trading program in Ningbo Dahongying University as an example, to analysis commodity trading program by "six-dimensional synergy" school-enterprise cooperation model, as the achievements they obtained in Talents training, teaching teams, curriculum construction, practice platform, the teaching process, and the student employment.
\end{abstract}

\section{Introduction}

Over the last decade, with the continuous expansion of higher education, in order to meet the needs of national construction and economic development, to deal with society's growing demands for higher education, China has established (including upgrading) a large number of colleges and universities. The goals of these colleges and universities are different from academic universities, they provide services directly to the local industry and business to promote regional economic development. So, school-enterprise cooperation is the key to achieving goals to cultivating applicable talents for these colleges and universities.

In 2011, the State Council officially approved the "the planning of Zhejiang Ocean economic development demonstration area", in which the commodity industry has become a key strategy for the Zhejiang ocean economic development. As the demonstration area of Zhejiang ocean economic development, Ningbo undertakes the important task of building the "trinity" of port and shipping logistics service system, in which current commodity talent training is a kind of scarce resource. In this context, Ningbo Dahongying University take commodity trading talent cultivating as an important measure of serving and promoting regional economic development, they corporate with "commodity research strategic alliance", which consists of 33 well-known domestic enterprises in commodities area including Ningbo Sunhu Chem. Products Co., LTD., Beijing Great wall Enterprise Institute, etc., to jointly build a talent training program based on the real industry standards, and format the mechanism of training the shortage talent adapting industrial development.

As higher education diversification, how to position application-oriented colleges and universities in a clear premise, to explore the school-enterprise cooperation model with "applied" and "undergraduate education" characteristics is critical.

\section{How to construct the School-Enterprise corporation Model in Commodities talent training}

In September 2014, International Economics and Trade (commodity trading) program in Ningbo Dahongying University is approved to be one of the Zhejiang emerging specialty construction projects, which is to train students specializing in commodity trading capabilities, commodity circulation skills, and the commodity application skills.

At the beginning of the program construction, the commodities trading program locate itself in the cooperation with enterprises to carry out talent training, after years of constant collaboration and discussion, the program has formed a "six-dimensional synergy" school-enterprise cooperation model. 


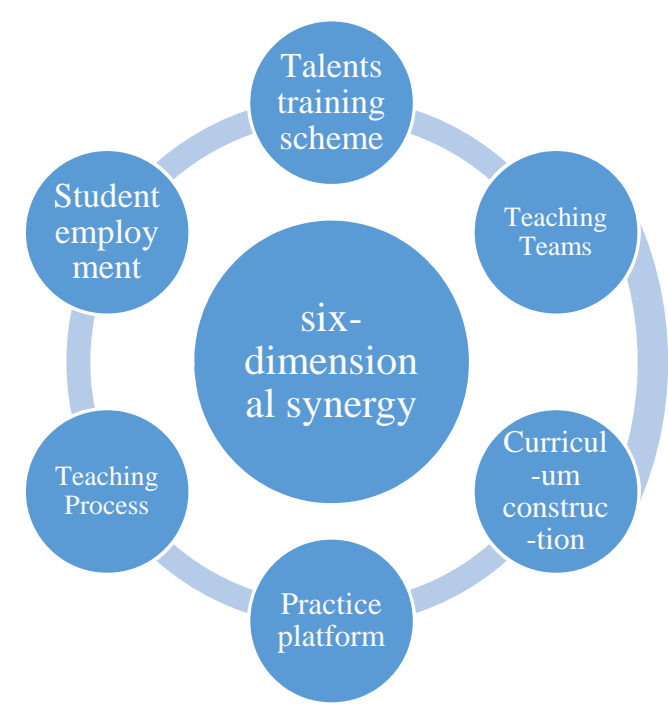

Fig.1 Commodity trading program "six-dimensional synergy" school - enterprise cooperation model

\section{Practice based on school-enterprise cooperation model of commodity trading program Training}

2.1 Talent Training scheme. The talent training scheme is based on professional cultivation objectives and specifications for the implementation of the concrete scheme of training activities, is the logic starting point of professional talent training objective and specification, content and method, condition and guarantee, of training process and the way of description and design. The scheme of commodity trading program mainly involves professional training objectives, the basic requirements of professional training, curriculum, professional capacity training and so on.

From the initial idea of the commodity program to the officially approved as Zhejiang emerging specialty construction projects, the training program scheme came out after numerous discussions. Especially with 33 domestic commodity investment and well-known enterprises including the Ningbo Sunhu Chem. Products Co., LTD., Beijing Great wall Enterprise Institute, formed a "commodity research strategic alliance" to jointly build the talent training plan based on industry standards, and according to the social changes in the economy, and invite experts in school-enterprise cooperation enterprise to demonstrate the training program.

2.2 Teaching teams. Cultivating applicable talents emphasizes not only on a solid theoretical foundation, but also pay more attention to practical ability, the special nature of this talent training requires teachers not only meet the psychological quality, professional ethics external quality, expertise and quality of scientific research and other professional quality as in academic colleges, but also need to have the ability to apply their knowledge, technical operations ability, practical organizational skills, ability to apply innovation. Currently, the teachers in colleges and universities lack experience, how to solve this problem is of great importance.

Commodity trading program applied the school-enterprise cooperation model, and has built an application-oriented teaching team. At present, the program has 50 teachers and instructors, where 21 full-time teachers and 29 part-time instructors. All part-time instructors come from the research alliances and collaborative innovation business enterprise. So all teachers and instructors are capable to combat in the real commodity industry, which provided a strong guarantee for the commodity trading program.

2.3 Curriculum construction. In order to achieve commodity trading training objectives and program construction, cultivating scarce commodity-related talents, develop course content and teaching methods implemented by school-enterprise cooperation. All textbooks and teaching materials are developed by five steps: Firstly, Curriculum design; Secondly: survey of the course; Thirdly: invite experts and managers in commodity industry to give lectures, the record of the 
whole lecture will be upload online for teachers and students learning repeatedly. After a round of teaching, the full-time teacher is in charge for supplement the relevant theoretical knowledge, and finally organizing handout materials, and at the same time building online courses by completing online course materials; Fourthly: Based on the current teaching materials, teaching another round, completing the entire theoretical system sound, using the actual cases, layout the course section, and add cases and exercises to supplement it, forming a first draft of teaching materials; Fifthly: consulting experts to review all materials, and then forming a textbook based on revision comments made by the experts, Repeatedly revised ready for publication.

Currently, commodity trading program joint commodity well-known enterprises, have developed the commodity series of teaching materials: "commodity introduction", "commodity logistics", "commodity purchasing and price management", "commodity trading", "commodity investment analysis "," Introduction to the commodity economy "six core courses' textbooks are officially published at Zhejiang University Press, the follow-up will develop three experimental materials, 1-2 overseas textbooks, five theoretical and practical teaching.

2.4 Practice Platform. Through cooperation with the Alliance of commodities research, the program has constructed the leading commodity experimental center, which consists of commodity trading laboratory, commodity finance laboratory, commodities logistics laboratory, commodities geographic information center laboratory, and the well-known CSMAR database. Developing commodity trading series with enterprises, could provide students with real experiments and practical support, could also provide teaching and research services for teachers, in order to facilitate social services and companies, they also built "Commodity Information Center" (website: www. dzspxx.com), to achieve an open, sharing platform.

Commodity trading program keeps close connection with the actual needs, closely linked to training objectives, and strengthen practical ability training, to build "proof, design, practical and comprehensive, "four in one" commodities trading experimental teaching system. In the teaching content development, the development and construction of a number of professional training for teaching content. For example, "commodity Introduction" developed commodity production and marketing cognition, the cognition and operation of commodities trading center, commodity varieties cognitive experiments project, "commodity logistics" course developed commodity trade and domestic distribution lines, "commodity trading", "investment analysis technology", "commodity purchasing and price management" and "commodity trading risk" course combined commodity industry, the actual development of the commodity $\mathrm{K}$ line, the price trend analysis, index analysis , point of purchase price, hedging, arbitrage and other combat projects, "commodity trading" "comprehensive e-commerce experiment" "commodity logistics comprehensive experimental" course developed commodity trading strategies, commodity e-commerce operation, commodity logistics design and simulation of integrated experimental projects.

The commodity trading program innovate the teaching schedule to a "12+4" structure, in which each term contains 12 teaching weeks and 4 weeks of concentrated practice. Experimental teaching courses intersperses within the 12-weeks teaching, and the special experimental stage is concentrated within 4 weeks concentrated practice, where managers and experts in enterprise will come to the lab and provide guidance for students.

2.5 Teaching Process. The commodity trading program is designed around the "learner-centered" teaching philosophy, discuss heuristic teaching, case teaching, discussion teaching, research and teaching reforms in teaching. Depth exploration of "the theoretical teaching + expert lecture + enterprise practice" teaching model, built "The undergraduate curriculum modules" to meet the commodities industry's demand, so that enterprises can choose and design for a specialized "curriculum modules", to promote school-enterprise cooperative teaching. Adopting the "commodity thematic Salon" into the curriculum, which is helpful to students to participate in seminars, training students to use expertise to carry out a comprehensive analysis.

The implementation of "the First, Second, and third classroom" in teaching, could improve the 
ability of applying knowledge. The First Class: based on the real business project to design teaching project as the carrier, enable students to acquire and master the real enterprise commodity-related knowledge and skills; The Second Class: Construct commodities-featured talents' core skills training platform: English salon and financial affairs Forum, instructed by a professional instructor, student self-management, as a student learning, communication, practice platform. The Third Class: students will participate in the real business projects,enable students to learn in reality.

2.6 Student employment. Commodity trading program provides extensive school-enterprise cooperation resources for student employment. In 2013, $100 \%$ graduates of the first "commodity-learning pilot class" (40 in total) find perfect jobs, 95\% of them get a "commodity-related" job, including over $30 \%$ of graduates working in the school-enterprise cooperation enterprise. In 2014, commodity trading program improve the depth of cooperation with enterprises for freshman, sophomore and junior, students, so some of them find their job before graduation.

\section{Conclusion}

The quality of student employment is directly related to the effectiveness of the Program construction. According to 2015 MyCOS report, using employment status, alumni evaluation, employment characteristics as the three program indexes, to evaluate commodities trading program. Concluded that: from session 2014, commodities trading program graduates perform better than those in other programs in non-unemployment rate, monthly income, turnover, etc. It is also above the school average. On the recommendation of alumni and the alumni satisfaction, commodity trading program also ranks first in the school, graduates in this program show very much agree with commodity trading program training model, they are willing to recommend the program to their friends and families. Session 2014 graduates mainly work in private enterprises and serve the local economy, which is a strong validation of the scientificity of in the commodities trading program "based in Zhejiang, the Yangtze River Delta," cultivating the applicable talents.

\section{Reference:}

[1]Ma cheng rong. Research on the mode of school enterprise cooperation[J]. Education and career, 2007(23)

[2]Xu ke jun, Huang yun zhi. Exploration and practice of cultivating innovative talents by cooperation between colleges and enterprises[J]. Chinese University Teaching,2014(7)

[3]Wang xudong. Local universities to improve the level of school through social services[J]. Higher education in China,2015(3)

[4]Commodity business college.Commodity business college characteristic material compilation[R],2014.

[5]Wang rui, Xu miao jun. The Theory and Practice of The New Format Social Service of Commodities Under The Mode of "double colleges "[J]. Journal of Ningbo Dahongying University,2016(3) 